\title{
Sleep and musculoskeletal complaints among elite athletes of Santa Catarina*
}

\author{
Sono e queixas musculoesqueléticas de atletas de elite catarinenses
}

Fernanda Tolentino de Souza Bleyer ${ }^{1}$, Diego Grasel Barbosa ${ }^{1}$, Rubian Diego Andrade', Clarissa Stefani Teixeira², Érico Pereira Gomes Felden ${ }^{1}$

${ }^{*}$ Received from University of the State of Santa Catarina, Florianópolis, SC, Brazil.

DOI 10.5935/1806-0013.20150020

\section{ABSTRACT}

BACKGROUND AND OBJECTIVES: There are many physiological processes going on during sleep which are important for physical and emotional balance and especially for motor function, essential for athletes' performance. This study aimed at investigating associations between sleep duration and quality and musculoskeletal complaints among elite athletes of the state of Santa Catarina.

METHODS: Four hundred and fifty-two athletes from various sports have been investigated on issues related to sleep (duration, quality) and musculoskeletal complaints in body parts through the Pittsburgh Sleep Quality Index and the Nordic Musculoskeletal Questionnaire, respectively. The association between sleep and muscle pain was analyzed by Spearman's correlation of "number of painful body parts" and "Pittsburgh Sleep Quality Index scores".

RESULTS: Mean age of athletes was 21.16 years (5.82), being $61.1 \%$ females and $38 \%$ with poor sleep quality and association between the amount of nighttime awakenings with nocturnal pain ( $\mathrm{p}<0.001)$.

There has been high prevalence of musculoskeletal pain, more evident on knees, shoulders, ankle/feet and low back. The number of painful parts was correlated $(r=0.216)$ with higher Pittsburgh Sleep Quality Index scores $(\mathrm{p}<0.001)$.

CONCLUSION: Athletes had high prevalence of poor sleep quality and musculoskeletal pain complaints, especially on knee, shoulders, back and ankle/feet. The correlation between poor sleep quality and pain was more evident as the number of affected body parts increased. Athletes with poorer sleep quality had more pain as compared to those with sleep duration changes, suggesting that musculoskeletal complaints are associated to athletes' sleep quality rather than to sleep duration.

Keywords: Athletes, Health, Performance, Sleep.

1. University of the State of Santa Catarina, Florianópolis, SC, Brazil

2. Federal University of Santa Catarina, Florianópolis, SC, Brazil.

Submitted in January 31, 2015.

Accepted for publication in May 13, 2015.

Conflict of interests: none - Sponsoring sources: none.

Correspondence to:

Érico Pereira Gomes Felden

CEFID/UDESC

Rua Paschoal Simoni 358

88080-350 Florianópolis. SC, Brasil.

E-mail: ericofelden@gmail.com

(C) Sociedade Brasileira para o Estudo da Dor

\section{RESUMO}

JUSTIFICATIVA E OBJETIVOS: Durante o sono, ocorrem inúmeros processos fisiológicos que são importantes para o equilíbrio físico, emocional e principalmente para o funcionamento motor, essencial para o desempenho do atleta. $\mathrm{O}$ objetivo do presente estudo foi investigar as associaçóes entre duração e qualidade do sono e queixas musculoesqueléticas em atletas de elite catarinenses.

MÉTODOS: Quatrocentos e cinquenta e dois atletas de diversas modalidades esportivas, foram investigados em questôes relacionadas ao sono (duração, qualidade) e queixas musculoesqueléticas em partes corporais, por meio do Índice de Qualidade de Sono de Pittsburgh e o Questionário Nórdico de Sintomas Osteomusculares, respectivamente. Os dados foram analisados na associação sono e dor muscular usando correlação de Spearman de "número de partes do corpo com dor" e "pontuação do Índice de Qualidade de Sono de Pittsburgh".

RESULTADOS: A idade média dos atletas foi de 21,16 anos $(5,82)$, sendo $61,1 \%$ mulheres, $38 \%$ com qualidade do sono ruim, e associação entre a quantidade de despertares noturnos com dor noturna $(\mathrm{p}<0,001)$. Altas prevalências de queixas musculoesqueléticas mais evidentes nos joelhos, ombros, tornozelo/ pés e parte inferior das costas. $\mathrm{O}$ número de partes com dor foi correlacionado $(\mathrm{r}=0,216)$ com maiores pontuaçóes no Índice de Qualidade de Sono de Pittsburgh ( $\mathrm{p}<0,001)$.

CONCLUSÁO: Os atletas apresentam altas prevalências de qualidade do sono ruim e de queixas dolorosas musculoesqueléticas, principalmente em joelho, ombro, costas e tornozelos/pés. A correlação da qualidade de sono ruim e dores ficaram mais evidentes na medida do aumento das partes corporais afetadas. Atletas com pior qualidade do sono apresentaram quadro álgico mais evidente do que aqueles com alteraçáo da duração do sono, sugerindo que as queixas musculoesqueléticas estejam mais associadas à qualidade do sono do que à duração do sono do atleta. Descritores: Atletas, Desempenho, Saúde, Sono.

\section{INTRODUCTION}

Human beings should remain sleeping for most of the day, at least one third of it. Sleep is one of the most vital physiological functions for life and is related to several fundamental events for the maintenance of health ${ }^{1-3}$. Within this 
context, studies describe physiological mechanisms which relate sleep to major issues of life, such as energy restoration $^{4,5}$, maintenance of immune system function ${ }^{6}$, neuronal plasticity promotion ${ }^{7}$ and growth hormone secretion ${ }^{8}$.

Sleep is also fundamental for athletes' good motor performance, especially considering the necessary recovery after hours of training ${ }^{9-13}$. Authors ${ }^{14-17}$ state in their studies that restorative and good quality sleep is in fact critical for athletes considering sports demands such as remaining alert during training and competitions.

It is known that elite sports should not be a priori considered synonym to health ${ }^{18,19}$, considering the negative events that training, aiming at sports performance, may bring to athletes, with emphasis to constantly living with pain. Studies on motor performance show high prevalence of pain, such as the study by Dore $\&$ Guerra $^{20}$ with professional ballet dancers, which has identified general prevalence of $70.2 \%$ of moderate and severe pain reaching $85.8 \%$ in the lumbar region.

So, it is necessary to more thoroughly understand possible variables which might prevent common pain among sportsmen and, in this sense, Atkinson \& Davenne ${ }^{21}$, and Halson ${ }^{13}$ state that adequate sleep improves athletes' general health status, decreasing the risk for injuries and pain.

Discussion about relations between sleep and pain is recent and needs to be deepened. Several authors discuss possible physiological mechanisms relating sleep to pain, considering, for example, that secretion of substances such as ghrelin would be involved with sensitivity to pain ${ }^{22-25}$.

It is observed that scientific studies support the relevance of sleep for sports performance and for the success of athletic competitions. However, it is possible to identify major scientific knowledge gaps about the sleep of athletes when associated to pain. One should also emphasize the lack of studies investigating the sleep-wake cycle in Brazilian athletes.

This study aimed at investigating associations between sleep duration and quality and musculoskeletal pain complaints in elite athletes of the state of Santa Catarina, Brazil.

\section{METHODS}

This study population was made up of athletes of different modalities, enrolled in the largest multisport competition of the state of Santa Catarina, Brazil, in which participate elite athletes of the state. Participate in this competition athletes of different Santa Catarina regions, after three eliminatory competitive stages (municipal, microregional and regional). Considering the population of athletes of the latest competition $(4,720)$ and for the sample to be representative, minimum number of athletes indicated by means of Rodrigues equation ${ }^{26}$ was 356 athletes, for a sample error of 5\%.

Athletes from different state regions, represented by delegations with the highest number of enrolled modalities were invited to be part of the sample.

After authorization of official agencies promoting the competition, delegations with the highest number of enrolled modalities were invited to participate in data collection. Questionnaires were anonymously answered by athletes agreeing to participate in the study, being supervised by researchers. Questionnaire had socio-demographic information on gender and age, in addition to evaluating sleeprelated issues and musculoskeletal complaints. Investigated variables and their respective tools were:

- Sleep duration: based on awakening and sleeping time during week days ${ }^{27}$;

- Quality of sleep: by Pittsburgh Sleep Quality Index (PSQI) ${ }^{28}$, with sleep-related questions according to the following components: 1) subjective sleep quality; 2) sleep onset; 3) sleep duration; 4) normal sleep efficiency; 5) sleep disorders; 6) use of sleeping pills; 7) daily somnolence and daily disorders. Each component has specific scores, being maximum score 21. Scores above five indicate poor sleep quality;

- Perception of body pain during sleep by means of the question: "How often have you had sleep problems due to pain?". Possible answers: "a) never last month, b) once or twice a week, c) less than once a week, d) three or more times a week". For the analysis of this variable we have categorized in [a) and c)] = little or no pain during the month; and $[b)$ and $d)]=$ one to three pain episodes during the week during the month;

- Night time awakenings: by means of the question:

"How often have you had sleep problems because you have awaked in the middle of the night or at dawn?" Possible answers: "a) never last month, b) once or twice a week, c) less than once a week, d) three or more times a week". For the analysis of this variable we have categorized in [a) and c)] = little or no pain during the month; and [b) and d)] = one to three pain episodes during the week during the month;

- Musculoskeletal complaints by means of the Nordic Musculoskeletal Questionnaire ${ }^{29}$. This questionnaire identifies the level of complaints for each body part (neck, shoulders, upper back, elbows, wrists/hands, low back, hip/thighs, knees and ankles/feet), and four questions were asked, for which answers could be "yes" (with pain) or "no" (no pain). Questions were: "Did you have problems such as pain, tingling/numbness on ... in the last 12 months?"; "Were you prevented from performing normal activities (for example: work, home activities, leisure) due to problems on ... in the last 12 months?"; Have you looked for some health professional (physician, physiotherapist) due to this condition on ... in the last 12 months?"; and "Have you had any problem on ... in the last seven days?" This tool was validated for Brazil by Pinheiro, Troccoli \& Carvalho ${ }^{30}$.

Descriptive analyses (means, frequencies and standard deviation) were performed. Kruskal-Wallis test was used to compare continuous variables among groups; and Chi-square test was used to check associations among variables. Spearman correlation was used to correlate variables "number of painful body parts" and "PSQI score". For all analyses significance level was $5 \%$.

This study was approved by the Ethics Committee for Research with Human Beings, UDESC (n. 666548 - 2013). 


\section{RESULTS}

Participated in the sample 276 female athletes and 176 male athletes, with mean age of 21.16 (5.83) years. A total of 622 questionnaires were distributed to athletes and response rate was $72.66 \%$ (452 returned). The prevalence of short duration of sleep ( $<8$ hours) was $48.5 \%$. In addition, $38 \%$ of the sample was considered as having poor sleep. Many athletes, $55.6 \%$ and $34 \%$, respectively, have reported sleep problems due to night time awakenings and pain during sleep (Table 1). There has been association between number of night time awakenings and night time pain $(\mathrm{p}<0.001)$.

Table 2 shows prevalence of musculoskeletal complaints according to body regions. With regard to pain, tingling/numbness in the last 12 months, there has been high prevalence on most investigated body parts, especially on knees (50.6\%),

Table 1. Sample descriptive data

\begin{tabular}{|c|c|}
\hline Variables & Index ${ }^{*}$ \\
\hline Age (years) & $21.16(5.82)$ \\
\hline Female (\%) & 61.1 \\
\hline Sleep duration $(\mathrm{h})$ & $7.9(1.45)$ \\
\hline Short duration of sleep (\%) & 48.5 \\
\hline PSQI (scores) & $5.09(2.47)$ \\
\hline Poor quality of sleep (\%) & 38.0 \\
\hline $\begin{array}{l}\text { Night time awakenings (none to less than once a } \\
\text { week) (\%) }\end{array}$ & 44.4 \\
\hline $\begin{array}{l}\text { Night time awakenings ( } 1 \text { or more than } 3 \text { per } \\
\text { week) (\%) }\end{array}$ & 55.6 \\
\hline $\begin{array}{l}\text { Pain during sleep (none to less than once a } \\
\text { week) (\%) }\end{array}$ & 65.6 \\
\hline Pain during sleep (1 or more than 3 per week) (\%) & 34.4 \\
\hline
\end{tabular}

shoulders $(47.5 \%)$ a low back $(45.7 \%)$. These parts, together with ankle/feet were those preventing the most athletes' daily life activities in the last 12 months. Lower limbs (knees and ankles/feet) were the parts leading more athletes to visit health professionals in the last year. Finally, knees and shoulders had highest acute effect of musculoskeletal complaints in the last 7 days.

Considering that knee was the joint with the highest prevalence of complaints on most investigated situations (problems with pain, tingling/numbness in the last 12 months, visit to health professionals and musculoskeletal problems in the last 7 days), figure 1 illustrates differences between mean sleep duration and PSQI scores between athletes with and without complaints. Based on this figure it is possible to identify that athletes with knee pain in the last 7 days had shorter sleep duration $(\mathrm{p}=0.036)$ and poor sleep quality $(\mathrm{p}=0.001)$.

Table 2. Prevalence of musculoskeletal complaints according to body regions

\begin{tabular}{|c|c|c|c|c|}
\hline Body parts & $\begin{array}{l}\text { *(1) }^{(1)} \text { ave you had prob- } \\
\text { lems such as pain, tin- } \\
\text { gling/numbness in the } \\
\text { last } 12 \text { months }\end{array}$ & $\begin{array}{l}*(2 \text { Were you prevented } \\
\text { from performing normal } \\
\text { activities in the last } 12 \\
\text { months }\end{array}$ & $\begin{array}{l}{ }^{*(3)} \text { Have you visited some } \\
\text { health professional in the } \\
\text { last } 12 \text { months }\end{array}$ & $\begin{array}{c}{ }^{*(4)} \text { Have you had some } \\
\text { problem on ... in the last } \\
7 \text { days }\end{array}$ \\
\hline Shoulders (\%) & 47,5 & 11,0 & 17,1 & 18,1 \\
\hline Upper back (\%) & 44,8 & 6,8 & 13,5 & 11,9 \\
\hline Low back (\%) & 45,7 & 11,3 & 16,0 & 15,8 \\
\hline Hip/thighs (\%) & 41,9 & 9,0 & 14,2 & 13,1 \\
\hline Knees (\%) & 50,6 & 15,8 & 24,8 & 25,5 \\
\hline Ankles/feet (\%) & 43,9 & 16,9 & 23,2 & 16,9 \\
\hline
\end{tabular}

\footnotetext{
* Nordic Questionnaire domains for body parts with musculoskeletal complaints.

(1) "Have you had problems such as pain, tingling/numbness on ... in the last 12 months?"

(2) Were you prevented from performing normal activities (for example, work, home activities, leisure) due to a problem on ... in the last 12 months?"

(3) "Have you visited some health professional (physician, physiotherapist) due to this condition on ... in the last 12 months?"

(4) "Have you had any problem on ... in the last 7 days?"

Source: Primary data (2014).
} 
Table 3 shows musculoskeletal complaints prevalence, according to groups with short sleep duration and with adequate duration and to good or poor sleep quality. These results indicate differences for most body parts considering sleep quality, that is, those athletes with poor sleep quality had more frequent musculoskeletal complaints. As example, it is possible to mention the higher number of significance for all Nordic questionnaire domains in our analysis for

Table 3. Prevalence of musculoskeletal complaints according to body regions and sleep duration and quality of athletes

\begin{tabular}{|c|c|c|c|c|c|c|}
\hline Body parts & \multicolumn{3}{|c|}{ Sleep duration } & \multicolumn{3}{|c|}{ Sleep quality } \\
\hline \multicolumn{7}{|c|}{ Have you had problems such as pain, tingling/numbness in the last 12 months? } \\
\hline Shoulders (\%) & 50.2 & 50.9 & 0.372 & 44.4 & 52.7 & 0.089 \\
\hline Upper back (\%) & 46.2 & 43.5 & 0.574 & 40.7 & 51.5 & $0.027^{\star}$ \\
\hline Wrists/hands (\%) & 25.6 & 34.0 & 0.088 & 23.8 & 39.5 & $0.001^{*}$ \\
\hline Low back (\%) & 42.7 & 49.8 & 0.138 & 41.1 & 53.3 & $0.013^{\star}$ \\
\hline Hip/thighs (\%) & 41.3 & 42.6 & 0.792 & 36.4 & 50.9 & $0.003^{*}$ \\
\hline Knees (\%) & 49.3 & 52.9 & 0.460 & 46.5 & 57.2 & $0.030^{\star}$ \\
\hline Ankles/feet (\%) & 44.4 & 44.5 & 0.991 & 38.9 & 52.1 & $0.007^{*}$ \\
\hline Upper back (\%) & 2.2 & 12.0 & $<0.001^{*}$ & 4.0 & 11.4 & $0.003^{\star}$ \\
\hline Elbows (\%) & 0.9 & 1.9 & 0.265 & 0.7 & 3.0 & 0.087 \\
\hline Wrists/hands (\%) & 6.3 & 9.1 & 0.360 & 5.8 & 10.2 & 0.064 \\
\hline Low back (\%) & 7.6 & 15.8 & $0.007^{\star}$ & 8.4 & 16.2 & $0.012^{*}$ \\
\hline Hip/thighs (\%) & 8.0 & 10.0 & 0.456 & 6.9 & 12.6 & $0.044^{*}$ \\
\hline Knees (\%) & 14.2 & 18.2 & 0.262 & 13.8 & 18.6 & 0.183 \\
\hline Ankles/feet (\%) & 19.6 & 14.8 & 0.193 & 13.8 & 21.6 & $0.035^{\star}$ \\
\hline \multicolumn{7}{|c|}{ Have you visited any health professional in the last 12 months? } \\
\hline Neck (\%) & 8.9 & 6.2 & 0.295 & 6.2 & 9.6 & 0.187 \\
\hline Knees (\%) & 22.7 & 27.8 & 0.222 & 22.5 & 28.1 & 0.186 \\
\hline Ankles/feet (\%) & 27.6 & 19.6 & 0.052 & 20.0 & 28.1 & $0.049^{\star}$ \\
\hline \multicolumn{7}{|c|}{ Have you had problems on .. in the last 7 days } \\
\hline Neck (\%) & 8.0 & 10.5 & 0.363 & 8.4 & 10.8 & 0.96 \\
\hline Shoulders (\%) & 17.9 & 19.1 & 0.731 & 16.1 & 16.6 & 0.146 \\
\hline Upper back (\%) & 11.1 & 13.4 & 0.469 & 9.1 & 16.8 & $0.016^{\star}$ \\
\hline Elbows (\%) & 2.7 & 5.7 & 0.108 & 2.2 & 7.2 & $0.010^{*}$ \\
\hline Wrists/hands (\%) & 8.0 & 15.8 & $0.012^{*}$ & 7.3 & 18.6 & $<0.001^{*}$ \\
\hline Low back (\%) & 15.1 & 17.2 & 0.550 & 12.0 & 21.6 & $0.007^{\star}$ \\
\hline Hip/thighs (\%) & 12.4 & 13.9 & 0.659 & 12.0 & 15.0 & 0.370 \\
\hline Knees (\%) & 21.8 & 30.6 & $0.036^{*}$ & 20.4 & 33.5 & $0.002^{*}$ \\
\hline Ankles/feet (\%) & 15.6 & 19.1 & 0.324 & 10.9 & 26.9 & $<0.001^{*}$ \\
\hline
\end{tabular}

* Significant result (Chi-square test for differences among proportions).

Source: Primary data (2014). 
ankles/feet.

With regard to sleep duration, there have been some differences indicating that athletes sleeping less than eight hours are more affected by musculoskeletal complaints. However, these differences were not so evident in all Nordic questionnaire domains, such as in comparing sleep quality and body parts.

In addition, as illustrated in figure 2, there has been positive correlation between the number of parts with pain and PSQI $(\mathrm{r}=0.216 ; \mathrm{p}<0.001)$, that is, the more parts with musculoskeletal complaints, the higher PSQI score, indicating poorer sleep quality. As to sleep duration, this analysis has identified just one correlation trend $(r=-0.090 ; p=0.061)$.

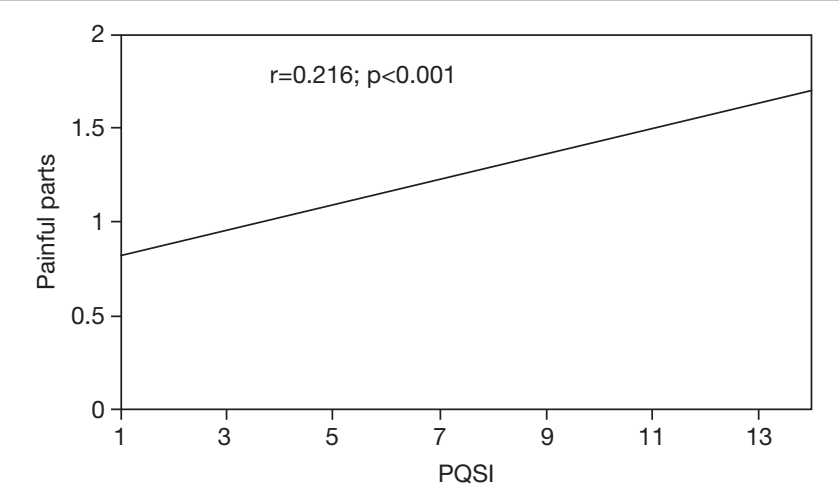

Figure 2. Correlations between the number of painful parts (musculoskeletal complaints) in the last seven days and Pittsburgh Sleep Quality Index scores (sleep quality).

PSQI = Pittsburgh Sleep Quality Index.

\section{DISCUSSION}

For high performance athletes, the act of transposing obstacles is a constant search for overcoming goals, to get to victory. In addition, it is necessary to face physical and psychological challenges, among them pain. So, living with pain or injury has to be somehow faced for their objective to be met ${ }^{18,19}$. The athletes of our sample have shown associations between sleep and musculoskeletal complaints, as well as poorer quality of sleep according to the number of affected body parts.

Considering night time awakenings and pain during sleep, there has been significant association among such athletes. This result is in line with Fietze et al. ${ }^{11}$ who have reported that night time awakenings somehow influence both sleep quality and pain sensation. These authors add that, the closer they are to important events, sleep architecture may change, impairing even further athletes' sleep quality.

So, follow-up studies are needed to establish cause and effect relationships between awakenings and pain. In principle, it is possible to question by considering a two-way path, because injuries may lead to night time awakenings and nights with poor sleep quality may increase the risk for injuries.

According to PSQI results in athletes of Santa Catarina, mean was 5.09 (2.47) and prevalence of poor sleep quality was $38 \%$. Confirming such results, the study of Fietze et al. ${ }^{11}$ has evaluated German professional ballet dancers and has found poor sleep quality indices in more than $50 \%$ of the sample. Brand et al. ${ }^{31}$ have observed similar indices, being 5.15 (1.14) for females and 5.41 (1.29) for males in PSQI scores for Swiss elite athletes from different modalities. The prevalence of poor sleep quality observed in athletes is in general high, such as in the sample of Samuels ${ }^{32}$, which was approximately $80 \%$ in Canadian athletes. So, it is suggested that education of sleep during training is necessary.

As to prevalence of musculoskeletal pain among athletes of Santa Catarina, there have been complaints regarding the last 12 months on investigated body parts, especially knees (50.6\%), shoulders (47.5\%) and low back (45.7\%). Similar study with professional dancers of the Northeastern region of Brazil has shown that sites most affected by pain were low back (85.8\%), followed by knees (59.6\%) and neck $(53.3 \%)^{20}$. In comparing both studies it is observed that the two most affected sites were knees and low back, only in a different order. In light of the above, it is noted a trend to force those muscles aiming at performance, both of dancers and athletes, being that both investigated populations were professionals representing the elite of their modalities.

Studies on sleep and pain in athletes are scarce. When observed in other populations, such as fibromyalgia patients, there is similarity of results indicating that better sleep quality is associated to less pain sensation, as reported by Marta et al. ${ }^{33}$; Moldofsky ${ }^{34}$; Tonial, Stechman Neto \& Hummig ${ }^{35}$. According to the prevalence of musculoskeletal complaints impairing the most the performance of daily life activities of athletes in the last 12 months, there are knees, shoulders, low back and ankles/feet. Most prevalent body parts which led athletes to look for some health professional in the last 12 months were knees (24.8\%), followed by ankles/ feet $(23.2 \%)$ and shoulders $(18.1 \%)$. So, it is possible to observe from percentages that lower limbs have taken more athletes to some health professional, since for daily life activities lower limbs directly participate in motion and actions as well as in fast return to training.

In line with this information, Astur et al. ${ }^{36}$ in their article, presented data collected during the II Brazilian Congress of Sports Arthroscopy and Traumatology in 2013 where sports physicians and orthopedists have shown that lower limbs injury and pain have led a higher number of athletes to look for help (97\% of cases). This confirms results found in our athletes who indicated that knees were the most affected part, with musculoskeletal complaints in all four analysis categories of the Nordic Musculoskeletal Questionnaire.

The three highest musculoskeletal complaints prevalence in the last 7 days were knees (25.5\%), shoulders (18.1\%) and ankles/feet $(16.9 \%)$. In the study by Pereira et al. ${ }^{37}$ with professional musicians, most affected joints in the last seven days were neck $(54.5 \%)$, shoulders $(50.0 \%)$ and upper back. It is possible to note that musculoskeletal complaints frequency is directly related to positions needed to perform 
different motor skills and that preventive measures should be planned according to detailed movement analysis.

In the athletes of our sample, poor sleep quality was significantly associated in the last 12 months to problems of pain/ tingling/numbness in all investigated body parts, except for shoulders. Pereira et al..$^{38}$, using a different tool to analyze "pain and physical complaints", have also found positive correlation between this variable and sleep quality. Similarly, Dore \& Guerra ${ }^{20}$ have observed positive correlations between quality of sleep and low back and neck pain.

Possible neurophysiological mechanisms connecting sleep to pain are being investigated by the literature and are focusing on the ghrelin issue ${ }^{22-25}$.

Guneli, Gumustekin \& Ates $^{23}$ discuss possible relations between ghrelin secretion and pain. Ghrelin, neuro-hormone secreted primarily by the stomach, links to its receptor at the arcuate nucleus of the hypothalamus. Ghrelin directly activates the neuropeptide $\mathrm{Y}$ (NPY) and indirectly inhibits proopiomelanocortin neurons (POMC) at the hypothalamus, thus increasing appetite. In addition, it was determined that NPY also modulates nociception in different areas of the central nervous system (CNS), inducing spinal antinociception and regulating pain in the brain. In addition, a POMC derivative, $b$-endorphine, is considered an endogenous keycomponent of the antinociceptive system.

Still according to Guneli, Gumustekin \& Ates $^{23}$, the antinociceptive effect is mediated by opioid receptors.

It should be stressed that opioid receptors-I activity is modulated by nitric oxide (NO). Considering that ghrelin has action in the increase of hypothalamic NO synthesis levels, it is possible that ghrelin, through NO pathway, may improve antinociceptive effects of endogenous opioids, showing its interaction with central opioid mechanisms. At the same time, ghrelin has anti-inflammatory effect. It inhibits pro-inflammatory cytokines IL-1b, IL-6 and TNF-a, which cause pain and other symptoms. On the other hand, sleep deprivation is associated to increased above-mentioned cytokines which may lead to hyperalgesia or increased sensitivity to pain.

Completing this mechanism, Dzaja et al. ${ }^{22}$ discuss the effect of sleep deprivation on nocturnal ghrelin secretion. In healthy male volunteers, ghrelin, cortisol and human growth hormone plasma levels were measured during two experimental sessions of 24 hours each. In the first, individuals have slept for eight hours (between 11 p.m. and 7 a.m.); in the second they were maintained awaken during the night. During sleep, ghrelin levels have increased in the first part of the night and have decreased in the morning. This nocturnal increase was abolished during sleep deprivation and ghrelin levels have just slightly increased until early morning. Ghrelin secretion during the first hours of sleep was positively correlated to growth hormone concentration peak. So, the conclusion is that nocturnal increase of ghrelin levels is more likely to be induced by sleep than by circadian influences. Still, during the first hours of sleep, ghrelin may contribute for growth hormone secre- tion and for promotion of slow waves sleep (stages 3 and 4 ), which is an especially restorative sleep stage for cognitive and physiological functions.

However, limitations of this study were the use of questionnaires to identify variables related to musculoskeletal complaints with regard to intensity; however, in large samples, this type of strategy allows for the development of athletes' baseline profile with regard to associated variables.

\section{CONCLUSION}

There has been high prevalence of poor sleep quality among elite athletes of Santa Catarina and almost half of them sleep less than eight hours. Important percentages of musculoskeletal complaints were also identified, especially on knees, shoulders, low back and ankles/feet. Poor sleep quality was associated to most joints, not being so evident for short sleep duration. Most athletes have reported awaking during the night, once or more than three times a week. And correlating musculoskeletal pain to PSQI this is even more evident, in the measurement of increased body parts affected in the athlete. Athletes with higher numbers of night time awakenings had more night time pain.

\section{REFERENCES}

1. Kryger M, Roth G, Eloni D, Dement W. Principles and Practice of Sleep Medicine $3^{\text {rd }}$ ed. Philadelphia: WB Saunders; 2005.

2. Mah CD, Mah KE, Kezirian EJ, Dement WC. The effects of sleep extension on the athletic performance of collegiate basketball players. Sleep. 2011;34(7):943-50.

3. Martins PJ, Mello MT, Tufik S. Exercício e sono. Rev Bras Med Esp. 2001;7(1):28-36

4. Berger RJ, Phillips NH. Energy conservation and sleep. Behav Brain Res. 1995;69(12):65-73.

5. Berger RJ, Philips N. Sleep and energy conservation. Physiology. 1993;8(6):276-81.

6. Ruiz FS, Andersen ML, Zager A, Martins RC, Tufik S. Sleep deprivation reduces the lymphocyte count in a non-obese mouse model of type 1 diabetes mellitus. Braz J Med Biol Res. 2007;40(5):633-7.

7. Fernandes RM. O sono normal. Medicina (Ribeirao Preto). 2006;39(2):157-168.

8. Van Cauter E, Latta F, Nedeltcheva A, Spiegel K, Leproult R, Vandenbril C, et al Reciprocal interactions between the GH axis and sleep. Growth Horm IGF Res. 2004;14(Suppl. A):S10-7.

1. 9. Belenky G, Wesensten NJ, Thorne DR, Thomas ML, Sing HC, Redmond DP, et al. Patterns of performance degradation and restoration during sleep restriction and subsequent recovery: a sleep dose-response study. J Sleep Res. 2003;12(1):1-12.

10. Brand S, Beck J, Gerber M, Hatzinger M, Holsboer-Trachsler E. 'Football is good for your sleep': favorable sleep patterns and psychological functioning of adolescent male intense football players compared to controls. J Health Psychol. 2009;14(8):1144-55.

11. Fietze I, Strauch J, Holzhausen M, Glos M, Theobald C, Lehnkering H, et al. Sleep quality in professional ballet dancers. Chronobiol Int. 2009;26(6):1249-62.

12. Gerber M, Holsboer-Trachsler E, Pühse U, Brand S. Elite sport is not an additional source of distress for adolescents with high stress levels. Percept Mot Skills. 2011;112(2):581-99.

13. Halson SL. Sleep and the elite athlete. Sports Science. 2013;26(113):1-4.

14. Walker MP, Brakefield T, Morgan A, Hobson JA, Stickgold R. Practice with sleep makes perfect: sleep-dependent motor skill learning. Neuron. 2002;35(1):205-11.

15. Postolache TT, Hung TM, Rosenthal RN, Soriano JJ, Montes F, Stiller JW Sports chronobiology consultation: from the lab to the arena. Clin Sports Med. 2005;24(2):415-56.

16. Leger D, Elbaz M, Raffray T, Metlaine A, Bayon V, Duforez F. Sleep management and the performance of eight sailors in the Tour de France a la voile yacht race. J Sports Sci. 2008;26(1):21-8.

17. Mah CD, Mah KE, Dement WC. Athletic performance improvements and sleep extension in collegiate tennis players. Sleep. 2009;32:A155-A.

18. Moura PV, Silva EA, Silva PP, Freitas CM, Caminha ID. O significado da dor física na prática do esporte de rendimento. Rev Bras Ciênc Esporte. 2013;35(4):1005-19.

19. Silva EM, Rabelo I, Rubio K. A dor entre atletas de alto rendimento. Rev Bras Psicol Esporte. 2010;3(1):79-97.

20. Dore BF, Guerra RO. Sintomatologia dolorosa e fatores associados em bailarinos profissionais. Rev Bras Med Esporte. 2007;13(2):77-80. 
21. Atkinson G, Davenne D. Relationships between sleep, physical activity and human health. Physiol Behav. 2007;90(2-3):229-35.

22. Dzaja A, Dalal MA, Himmerich H, Uhr M, Pollmächer T, Schuld A. Sleep enhances nocturnal plasma ghrelin levels in healthy subjects. Am J Physiol Endocrinol Metab. 2004;286(6):E963-7.

23. Guneli E, Gumustekin M, Ates M. Possible involvement of ghrelin on pain threshold in obesity. Med Hypotheses. 2010;74(3):452-4.

24. Homann D, Louzada FM, Góes SM, Roizenblatt S, Lopes AL, de Oliveira AR, et al. Acylated ghrelin: a potential marker for fibromyalgia? Eur J Pain. 2013;17(8):1216-24.

25. Weikel JC, Wichniak A, Ising M, Brunner H, Friess E, Held K, et al. Ghrelin promotes slow-wave sleep in humans. Am J Physiol Endocrinol Metab. 2003;284(2):E407-15.

26. Rodrigues PC. Bioestatística. $3^{\text {rd }}$ ed. Niterói: Editora da Universidade Federal Fluminense; 2002.

27. Louzada F, Menna-Barret L. Sleep-wake cycle in rural populations. Biol Rhythm Res. 2004;35(1-2):153-7.

28. Buysse DJ, Reynolds CF 3rd, Monk TH, Berman SR, Kupfer DJ. The Pittsburgh Sleep Quality Index: a new instrument for psychiatric practice and research. Psychiatry Res. 1989;28(2):193-213.

29. Kuorinka I, Jonsson B, Kilbom A, Vinterberg H, Biering-Sorensen F, Andersson G, et al. Standardized Nordic questionnaires for the analysis of musculoskeletal symptoms. Appl Ergon. 1987;18(3):233-7.

30. Pinheiro FA, Troccoli BT, Carvalho CV. [Validity of the Nordic Musculoskeletal
Questionnaire as morbidity measurement tool. Rev Saude Publica. 2002;36(3):30712. Portuguese.

31. Brand S, Beck J, Gerber M, Hatzinger M, Holsboer-Trachsler E. Evidence of favorable sleep-EEG patterns in adolescent male vigorous football players compared to controls. World J Biol Psychiatry. 2010;11(2):465-75.

32. Samuels C. Sleep, recovery, and performance: the new frontier in high-performance athletics (Reprinted from Neurol Clin. 2008;26(1):169-80). Phys Med Rehabil Clin N Am. 2009;20(1):149-59.

33. Marta IE, Baldan SS, Berton AF, Pavam M, da Silva MJ. [The effectiveness of therapeutic touch on pain, depression and sleep in patients with chronic pain: clinical trial]. Rev Esc Enferm USP. 2010;44(4):1100-6. Portuguese.

34. Moldofsky H. Sleep and pain. Sleep Med Rev. 2001;5(5):385-96.

35. Tonial LF, Stechman Neto J, Hummig W. [Chronic pain related to quality of sleep]. Einstein. 2014;12(2):159-63. English, Portuguese.

36. Astur DC, Novaretti JV, Uehbe RK, Arliani GG, Moraes ER, de Castro Pochini A, et al. Muscle injury: current perspectives and trends in Brazil. Rev Bras Ortop. 2014;49(6):573-80.

37. Pereira EF, Kothe F, Bleyer FT, Teixeira CS. Work-related stress and musculoskeletal complaints of orchestra musicians. Rev Dor. 2014;15(2):112-6.

38. Pereira EF, Teixeira CS, Kothe F, Díaz Merino EA, Etchepare Daronco LS. Sleep quality and quality of life perception in orchestra musicians. Rev Psiquiat Clin. 2010;37(2):48-51. 